\title{
COVID-19 y SARS-CoV-2
}

\section{COVID-19 and SARS-CoV-2}

\author{
Alfredo Pinzón-Junca • Bogota, D.C. (Colombia)
}

DOI: https://doi.org/10.36104/amc.2020.2052

Durante la actual pandemia se están viendo usos incorrectos de algunos términos científicos relacionados, que en este caso corresponden a siglas o acrónimos provenientes del idioma inglés, pero que en nuestra lengua deben respetar las normas de la ortografía española.

- COVID-19: Enfermedad producida por el nuevo Coronavirus SARS-CoV-2. [inglés: Coronavirus disease 2019 (COVID-19)]. Al acrónimo COVID le corresponde artículo o determinantes femeninos, puesto que el núcleo de la denominación abreviada es el sustantivo femenino enfermedad. Además, por norma, las letras que forman siglas se escriben con mayúscula y sin puntos, sobre todo cuando conforman acrónimos.

- SARS-CoV-2: Coronavirus tipo 2 relacionado al síndrome respiratorio agudo severo. [inglés: Severe acute respiratory syndrome-related coronavirus type 2]. Este acrónimo lleva artículo o determinantes masculinos, ya que el núcleo de la expresión que se abrevia es el sustantivo masculino virus. Por norma internacional, en su escritura se debe respetar el uso de mayúsculas, minúsculas y guiones de la denominación original.

- Coronavirus: Género de virus de la familia Coronaviridae con viriones ARN de cadena positiva y genoma largo, que están cubiertos por una cápside, sobre cuya superficie emerge una corona de glucoproteínas con forma de bastón. [inglés: coronavirus]. Como género, se escribe en cursiva y con mayúscula inicial. Como nombre propio, no suele ir precedido de artículo, pero si lo precisa, es masculino.

Por lo tanto, las formas correctas para el uso de estos términos son:

\section{$\checkmark \quad$ La COVID-19 \\ $\checkmark$ EI SARS-CoV-2 \\ $\checkmark$ El Coronavirus}

\section{Fuentes}

- Gorbalenya A. E. et al. The species Severe acute respiratory syndrome-related coronavirus: classifying 2019-nCoV and naming it SARS-CoV-2. Nature Microbiology 2020, (5)536-544. https://doi.org/10.1038/s41564-020-0695-z

- International Committee on Taxonomy of Viruses (ICTV). www.talk.ictvonline.org

- Organización Mundial de la Salud. www.who.int/es

- Real Academia Nacional de Medicina. Diccionario de Términos Médicos. Editorial Médica Panamericana. 2012

- Departamento de «Español al día». Real Academia Española

- Real Academia Española. Ortografía de la lengua española. Espasa Libros. 2010

Dr. Alfredo Pinzón-Junca: Especialista en Medicina Interna y Psicoanálisis. Hospital Universitario de La Samaritana y Hospital Simón Bolívar. Coordinador del Consejo de Acreditación y Recertificación de la ACMI ${ }^{\circledR}$. Bogotá, D.C. (Colombia).

E-mail: alfpin@hotmail.com

Recibido: 21/X/2020 Aceptado: 28/X/2020 